\title{
Reform \& Practice on the Diversification of the Examination Mode of Applied Undergraduate Education
}

\author{
Changyu Li and Guixia Ma \\ Changchun Institute of Technology Changchun 130012
}

Email: 494106544@qq.com

Keywords: Application-oriented; Examination mode; Teaching reform

\begin{abstract}
According to our school's training target for basic industry base of applied talents, our school has set up a mode which is in accordance with the school talent training target and diversified tests of social needs. Meanwhile, our school has achieved the goal to cultivate students' ability to apply for the organic combination of teaching and examination mode. Especially, the teaching scheme and the assessment outline of practicing teaching link has strengthened the students' application ability and the cultivation of engineering quality, which has also achieved good results in teaching practice.
\end{abstract}

\section{Introduction}

Education examination is very important in the learning process of students across the university education activities. By means of the test, students can improve their learning efficiency and effectiveness, and promote the improvement of their knowledge, ability and quality [1].

Test is based on the education purpose stipulated in the talent training scheme to assess students' learning situation. It is also one of the important methods used to test the teacher's teaching. Examination focus reflects the students' mastery on the basic concepts, basic theory, and basic skills, and the ability of analytical skills and problem solving skills. It also reflects the level of institutions of higher learning undergraduate education and a basic approach to realize the goal of talent cultivation. Through the course examination, it can not only evaluate the degree that students' have mastered of their learning courses, and assess the teachers' teaching achievements, and promote the teachers' consciousness to improve teaching level and teaching quality, but it is also the reflection of the school curriculum construction level and the embodiment of the concept of running school. In this paper, based on a provincial teaching reform project "reform and practice on applied undergraduate formative course examination mode" and the key subject of Jilin province department of education "reform the students' academic appraisal system , promote the study style construction, improve the personnel training", it is committed to the reform of applied undergraduate education test mode diversification, to establish the school talent training target and social needs of curriculum evaluation system, so as to meet the need of applied talents training and examination content. It has achieved good results in teaching practice [2-5].

\section{Examination and Appraisal Reform is to Adapt to the Need of Applied Talents Training}

Our school in the tenth-five year plan clearly put forward: to foothold in Jilin, facing the whole country, relying on industry, service at the base, based on education, with an emphasis on engineering undergraduate education of engineering management arts and multidisciplinary cross coexist, close combination, cultivating entrepreneurial consciousness, innovation ability and strong engineering practice ability of senior applied talents of school-running orientation.

To achieve the goal of applied talents cultivation, the primary thing is that in the teaching process, the teacher should not only impart knowledge to students, but make students apply learned knowledge to the production practice under the premise of mastering knowledge. This requires us to change the traditional test methods and explore a set of scientific and reasonable test methods.

To develop scientific and reasonable test methods is helpful to arouse the enthusiasm of teachers to improve teaching methods; to arouse students' pertinence, purpose, learning enthusiasm and 
initiative; to promote students to form good learning atmosphere; to mobilize schools for unit of each teaching link to participate in the supervision and inspection of strength, promoting the school examination. The school's teaching, learning atmosphere and examination ethos are related to the school's social reputation and education quality [6]. Therefore, in order to create the national first-class university of applied undergraduate, and to produce more senior applied undergraduate talents for society facing the line at the base. The school must adopt reasonable test methods.

\section{The Main Problems of Current Examination and Appraisal Model}

Current Test Methods Can't Carry out the Applied Undergraduate Talents Training Target very Well. The majority of examination is given priority to summative examination results, and formative assessment and summative assessment can't organically combine together. Although the total score consists of the regular grades, the final grades and other parts, but at the end of the accounting period, the final examination grades is in high proportion, stage assessment seldom at ordinary times. For the problems existing in the teaching process cannot be found in time, it is difficult to grasp the initiative of students' participation in classroom and to fairly reflect the students' learning quality, so the purpose and function of curriculum evaluation is far from the desired effect. Students and teachers' attitude towards the course exam is only for the evaluation and assessment [7]. The teachers in teaching and students in learning can't carefully and systematically analysis the deficiency existing in the current teaching process through the inspection. For the teaching and learning process control does not reach the designated position, it affects the construction of undergraduate teaching and learning atmosphere, restricting the improvement of teaching quality.

Current Test Methods Restrict the Students' Personal Development. Traditional general exam class adopts hundred-mark system, the final exam accounts for $70 \% \sim 80 \%$, and the ordinary assessment result accounts for $20 \% \sim 30 \%$. The formative assessment link is weak, the proportion is low, and it can't fully mobilize students' initiative and creativity. "To work out the output, and test again assault" phenomenon is widespread. Especially in the form the closed-book exam, a test paper cannot contain the knowledge of all courses (link), and even some courses should be in the form of a work to show students mastery of knowledge points, instead of using the form of the closed-book exam. Thus it causes students cannot review comprehensively and the phenomenon of creative thinking killing to appear. Choosing to adapt to the diversification of evaluation methods, to be able to check the students' learned knowledge, the understanding of skills, the situation of mastering and using, it is helpful to examine students' comprehensive quality and practical application ability, to test students' learning effects and personality preferences, and to promote students' personal development.

Phase from the Test Content and Social Needs. Objective questions such as fill in the blanks, choice, and short answer ratio in the traditional examination are on the high side, while comprehensive thinking questions, analysis essay questions, the questions of solving the problem of the production practice are on the low side. The assessment content of the companies' interview in school curriculum evaluation content is not reflected, and the graduates novitiate enterprise training content in school curriculum evaluation content is still not reflected, and the professional course content phases from the social needs[8].

Current Test Methods are Unfavorable to the Cultivation of Students' Practical ability and Innovative ability. The base oriented senior applied undergraduate talents should have good practice ability and innovation ability. Practice ability and innovation ability are the use of classroom learning theoretical knowledge combined with extracurricular exploring and thinking and hands-on practice in order to cultivate. The pure exam cannot cultivate practice ability and innovation ability, for the exam is just testing some theory knowledge of master degree. After graduation, students will put the theoretical knowledge into a painting or a magnificent building, which will melt a lot of emotional experience of the students, direct experience and indirect experience harvest and so on[9]. This is the combination of the experience and book knowledge, and it is difficult to measure and obtain through examinations. 


\section{Reform and Practice of Learning and Assessment of Interactive Assessment Mode}

Established in Line with the Applied Talents Training Goal of Curriculum Evaluation System. Breaking the original exam class and test class boundaries, through independent thinking and innovative factors as important criteria of appraisal theory in the teaching process, through the process of strengthening examination and assessment of a variety of ways and the assessment content is given priority to ability, improving the inherent teaching mode, updating teaching content, guiding students to fully develop the innovation consciousness, improving students' application ability, so as to achieve to cultivate students ability to apply for the combination of teaching and examination mode.

Promote the Application Ability and Engineering Quality Development as the Main Line of Curriculum Evaluation Content. To construct the students' ability as the main building of course examination content and flexible examination types, to increase comprehensive and practical examination content, to strengthen the openness of the exam content properly and the ability of students' acquiring, processing, to use information and knowledge, as well as the analysis and problem solving skills, to guide students to study independently at ordinary times, society, the development of the industry information actively, promoting students' personalized development, so as to improve the students' application ability and engineering quality.

Breakthrough Tradition to Establish Various Test Methods. The traditional test most adopts the closed-book exam. Breakthrough the traditional test modes to change the closed-book exam into the combination of open-book and half open-book exam, to combine written exam, oral exam and network interactive teaching together, to combine works, essays and reports together, to combine online test and teaching-exam together.

To combine the closed-book exam, the open-book and the half open-book exam together

The half open-book exam is a form between the closed-book exam and the open-book exam, telling students about the testing methods before the teaching and distributing test papers to students. The test paper is expected to conclude the points learned, making students fully apply the test books and references to study during the whole process of studying. In the exam, students are allowed to take the test papers with them, but they cannot erase or write answers on them. The test questions are all based on the test papers. In our school, the course of electrical and electronic adopts this kind of test method; it fully arouses the students' enthusiasm and initiative. They get a general idea of the courses learned, the test form and the scope at the beginning of the term. Meanwhile, not only do the students well master the points, but ease the tension. This kind of test method will relieve students from the atmosphere of resistance, speculation and cater against teachers, and establish a strong mentor.

To combine written exam, oral exam and network interactive teaching together

For language courses in written, oral and the combination of network interactive teaching mode, it improves the students to learn the language better, to break the "only written, no spoken" form of the students. Our school English course founds the platform of Blackboard, realizing the network interactive teaching, establishing the multidimensional teaching forms. College English course carries out diversified modes of test and assessment, and the content and ways to the class are greatly stretched, and it fully excites the students' potential, and it also improves the students' synthetic application ability and creativity. In recent years, the rate of passing CET4 gradually increases.

To combine works, essays and reports together

For professional course, our school adopts to combine works, essays and reports together. In the past, during the professional course teaching and test, it stresses the result and operation, but neglects the process and thinking. There is too much homework, while less studies. The test mode is single, so students cannot completely bring the initiate into play. The form of combining works, essays and reports together requires the students to finish one essay or work from the given topics. Some courses of the art major in our school firstly try this kind of test mode, and the topic is closely related to the production practice. It requires students to refer to considerable information, and it also makes students deepen the comprehension and application of the knowledge [10]. 
To combine online test and teaching-exam together

Computer class is a practical course; the evaluation of student achievement should not be limited to the final exam. We combine the online test and the teaching-exam together, gradually making the paperless examination come true, putting the formative assessment and summative assessment together, establishing a perfect examination database, realizing the separation of teaching and examination. It enriches the teaching resource and also builds up a perfect online examination system. The basic computer course adopts this kind of test mode and it is applied to the teaching practice from 2007 to 2010, achieving a good effect. Students improve their ability to program a lot.

To combine the reasonable regular grades and the final grades together

Whether the attitude to study is correct or not directly influences the effect, thus the school should pay more attention to the regular study. The school should put an end to the phenomenon of lateness, early leave, absence and being absent-minded. Therefore, it can not only promote the students to form good learning atmosphere and also improve the study effect. Breaking the tradition to increase the proportion of regular grades, and change the regular grades to $50 \%$ in the overall. What's more, they should put proper grades on the class questioning, discussion, homework, study attitude, quizzes and periodical paper. It will make students accumulate partly grades of the course during the regular learning, and also make them form better study habits. Increasing the proportion of regular grades, abandoning the one-exam and lowering the exam stress will all objectively assess the students who work hard all the time but fail in the final exam. Practice has proved that the form of increasing the regular grades makes students keep calm in the final exam. Whereas, the school should advocate using various pony quizzes that emphasizing on the comprehensive abilities, saving students' time of preparing.

To Set up Scientific and Reasonable Performance Evaluation System. The assessment results of performance evaluation should pay attention to "five rules". That means firstly, the assessment of test must "quantified ", secondly, the first assessment must be humanized-warning the failed students to prepare for the next exam, thirdly, awarding for the strength, fourthly, making the students on both side of the ends "elastic"-giving the students who want to further their study more time, but they are required to meet the standard in the exam, while giving the students who want to work proper time, fifthly, specializing the objective reasons-objectively considering the sick leave, leave for personal affairs that resulting in absence.

The Quality Standards for Each Teaching Link and Examination Outline. On the basis of summary of practical experience in teaching carefully, further defined the practice teaching skills and ability to focus on training target, optimize the teaching contents and teaching process, make the appraisal basis, and through carefully write the practice teaching and its corresponding assessment program. Teaching practice teaching link teaching scheme is mainly composed of basic information, skills, and ability training objectives, teaching contents and teaching requirements, process arrangement, teaching methods and teaching means, teaching condition and the practice achievement, etc. Examination outline is mainly composed of assessment purposes (basic requirements), the examination content, evaluation standard, evaluation methods, results and evaluation, etc. Teaching plan and teaching practice and its corresponding examination outline writing, not only makes clear the aim of training students' skill and ability, strictly regulate the practice teaching content and assessment requirements, make practical teaching plan and process arrangement more carefully, earnestly implement the students' practice ability and engineering quality requirements.

\section{The Effect of Test and Examination Reform}

Resolving the Problem of the Light Weight Knowledge Ability, Adapting to the Requirement of Applied Talents. Applied undergraduate school curriculum examination content must be based on the syllabus. Through reform, in view of the different types of course using the appropriate appraisal way, attaining the unity of theory and practice. Teaching of theoretical knowledge to pass the exam to make students master the basic concepts, basic theory, basic skills, equipped with corresponding practice examination at the same time, it can improve students' ability to analyze 
problems, solve the problem. To pay equal attention to both theory and practice of the practical ability of students, their professional and comprehensive quality, personal special skill, and innovation ability will be improved greatly, and it also promotes the students' personality development. In order to improve the students' practical ability, the school also establishes close relationship with the domestic related industries more than hundreds of large and medium-sized enterprises, having built 131 off-campus practice base "industry-university-institute" cooperation, to send the students who pass the theoretical study to off-campus practice base, greatly improving the students' ability of combining theory with practice.

Resolving the Problem of Single Course Assessment Form, and Proving the Effective Guarantee for the Talent Training Scheme and Ability of Implementation of the Outline. The original single test method is simple and rigid; students' cannot develop their personalities. And it cannot effectively distinguish the difference that how the students master knowledge, yet cannot best check on the quality and ability of the students. Through test method reform, students' learning initiative and creative are well developed, their hands-on operation and the social practice ability has been fully cultivated, and their learning quality has been greatly improved. Each year, our school graduates further the number of domestic well-known university graduate student in more than 200 people each year.

Revolving the Problem of Taking Examinations as the only Method to Test Students, and Combining the Learning and Practice Together. Applied undergraduate education is the guarantee of the applied talents who have basic and outstanding ability.

Test method reform has changed the students' learning drab and the state of being afraid of taking an examination, has also increased the scope of students outside learning. It makes students participate in various knowledge contest held by school, and all kinds of club activities, and gain the outstanding achievements in the college students' activities held by the province or the city.

Revolving the Problem of Narrow-Covered Exams and the Unreasonable Structure of the Content, and Improving the Students' Practice Ability. New test methods have proved that the phenomenon of teacher delimiting the scope of teaching materials, students reviewing only the strengthening points before exams, memorizing the answers and copying notes have decreased significantly. It makes students walk out of the limited textbooks and form the good style of study. It also inspires the students' interest in learning, expands the coverage of knowledge, inspires the students' learning enthusiasm and creativity, improve the students' study effect, make the students' knowledge structure more incline to be reasonable, improve students' comprehensive quality. As a result, students all take an active part in the project of college students' innovative entrepreneurial training plan, as well as national, provincial or municipal undergraduate course contests. At the same time, the innovation ability of students obtained the judges' and the experts' high praise. In recent years, in the "challenge cup" national university student extracurricular academic science and technology works competition ", "the ninth national robot competition and FIRA world robot competition 2009", and other national and provincial contests of the communist party of China, our school has more than 800 students won the prize.

Revolving the Problem of the Unreasonable Question Styles, the High Proportion of Objective Questions but Little Thinking and Analysis Questions. When draw objective questions and subjective questions for determining the appropriate scale, improve the test reliability and validity. Check and inspection on the integrity of students' knowledge structure and the ability to solve the problem is more and more close to the nature of science. It makes for the cultivation of the talent.

Reducing the subjective topic and increasing the objective is helpful to cultivate the students' ability of finding, analyzing and solving problems. It is also beneficial to the development of the students' oral expression ability, writing ability, the cultivation of divergent thinking and creative thinking. What's more, it will improve the efficiency, impartiality and fairness of the exam.

Revolving the Problem of Emphasizing the Details but Neglecting the Comprehensive Ability in Recent Test Forms, then Raising the Employment Rate. In the process of teaching assessment, examination paper is based on the syllabus, emphasizing the application of the 
comprehensive and highlighting for knowledge combination. No longer does it write separately according to the knowledge of each chapter, thus change the student's idea of a single, meticulous situation. It enhances the students' ability to master the knowledge of the whole structure, and helps the students to work in the future where they can flexibly master and integrate the use of learned knowledge. Our school graduates work across the country, it is their advantages that they have strong hands-on skills and they can work fast. They are the reflection of our school's motto. They are well praised by the social from all walks of life, especially the base institutions. Graduate employment rate has remained at a high level, among colleges and universities in Jilin province. School won a consecutive title "the advanced collective of employment management in Jilin province".

\section{Conclusion}

By advancing the reform of applied undergraduate education test mode diversification and practice, our school gradually achieves the result of thorough course examination, diversified assessment mode, competent examination content, and standardized examination management. At the same time, the curriculum evaluation lies in students' knowledge in the process of learning and ability training, and the knowledge learning and ability cultivating in course examination, so as to explore a mode that take ability cultivating and the formative assessment as the main core of course assessment. This mode will give full play to the course assessment in the teaching of detection, diagnosis, feedback and incentives, and promote students' development of knowledge, ability and quality, also the cultivation of innovation ability and practice.

\section{References}

[1] H. Yu, Discussion on the reform of medical cell biology examination[J], Journal of Shanxi Medical University (Preclinical Medical Education Edition)

[2] Q.Chen. On College Students' innovation ability in examination reform and Cultivation [J]. Exploration of Medical Education, 2008(07).

[3] N.Liu. Research on the model and guarantee mechanism of examination reform in Colleges and Universities [J]. Journal of Shenyang Construction University (SOCIAL SCIENCE EDITION), 2008(01).

[4] L.X.Chen. Exploration and Practice on the reform of the course examination in Colleges and Universities [J]. Journal of Tonghua Normal University, 2007(02).

[5] Y.Chen. Some thoughts on the reform of examination in Colleges and Universities [J]. Journal of Zhejiang Wanli University, 2006(03)

[6] Y.L.Wang. Quality education and examination reform in Colleges and Universities [J]. Journal of Jiangsu Institute of Education (SOCIAL SCIENCE EDITION), 2006(02)

[7] [.G.Liu. The cultivation of innovative talents and the reform of examination in Colleges and Universities [J]. Modern university education, 2006(02)

[8] Z.H.Wang. Practice and thinking of examination reform in Higher Medical Colleges [J]. Journal of Shanxi Medical University (basic medical education), 2005(05)

[9] L.J.Ding. Talking about the reform of university examination from the function of examination [J]. Journal of Nanchang Hangkong University (SOCIAL SCIENCE EDITION), 2002(01).

[10]H.Zou. Examination reform in Colleges and universities and the cultivation of College Students' innovation ability [J]. Journal of Guangdong radio and TV University, 2001(02) 